\section{9 update of the EULAR recommendations for the management of SLE: don't forget chloroquine}

Recently, the journal published the 2019 update of the European League Against Rheumatism (EULAR) recommendations for the management of systemic lupus erythematosus $(\mathrm{SLE})^{1}$ that we reviewed with great interest. It drew our attention that the lack of mention of chloroquine as another option in the treatment of SLE within the antimalarials drugs, considering this an important omission that should be taken into consideration. It is true that there is a lack of evidence when comparing with hydroxychloroquine but there are some studies that support its use as an equivalent. ${ }^{2-6}$ We also agree that because of having a safer drug profile with less side effects, hydroxychloroquine should be preferred over chloroquine; nevertheless, the availability in other regions of the world could be variable and also, we should take into consideration the higher cost of hydroxychloroquine over chloroquine that in middle-income and low-income countries could be a bigger consideration. We understand that the recommendations are aimed mostly to the European community, and even when there have been major efforts to counteract the geographic differences with the developing of recommendations adapted to every region, ${ }^{7-9}$ we believe from a global perspective that there are countries who continue supporting their clinical decisions on recommendations made by the most important associations in the world. This is the reason, we consider pertinent to highlight this observation.

\section{Gabriel Figueroa-Parra $\odot$, Carmen Magdalena Gamboa-Alonso, Ana Laura De-Leon-Ibarra, Dionicio Angel Galarza-Delgado}

Servicio de Reumatología, Hospital Universitario Dr José Eleuterio González, Monterrey, Mexico

Correspondence to Dr Dionicio Angel Galarza-Delgado, Servicio de Reumatología, Hospital Universitario Dr Jose Eleuterio Gonzalez, Monterrey 64460, Mexico; dgalarza@medicinauanl.mx

Contributors GF-P conceived the manuscript. GF-P, ALD-L-I, CMG-A and DAG-D drafted and revised the manuscript for important intellectual content.

Funding The authors have not declared a specific grant for this research from any funding agency in the public, commercial or not-for-profit sectors.

Competing interests None declared.
Patient consent for publication Not required.

Provenance and peer review Not commissioned; internally peer reviewed.

(c) Author(s) (or their employer(s)) 2020. No commercial re-use. See rights and permissions. Published by BMJ.

\section{Check for updates}

To cite Figueroa-Parra G, Gamboa-Alonso CM, De-Leon-Ibarra AL, et al. Ann Rheum Dis 2020;79:e114.

Received 13 May 2019

Accepted 17 May 2019

Published Online First 24 May 2019

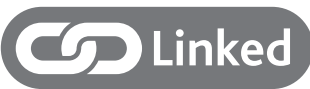

- http://dx.doi.org/10.1136/annrheumdis-2019-215746

Ann Rheum Dis 2020;79:e114. doi:10.1136/annrheumdis-2019-215716

ORCID ID

Gabriel Figueroa-Parra http://orcid.org/0000-0002-6077-8899

\section{REFERENCES}

1 Fanouriakis A, Kostopoulou M, Alunno A, et al. 2019 update of the EULAR recommendations for the management of systemic lupus erythematosus. Ann Rheum Dis 2019;78:736-45.

2 Meinão IM, Sato El, Andrade LE, et al. Controlled trial with chloroquine diphosphate in systemic lupus erythematosus. Lupus 1996;5:237-41.

3 Aviña-Zubieta JA, Galindo-Rodriguez G, Newman S, et al. Long-term effectiveness of antimalarial drugs in rheumatic diseases. Ann Rheum Dis 1998;57:582-7.

4 Wozniacka A, Lesiak A, Narbutt J, et al. Chloroquine treatment influences proinflammatory cytokine levels in systemic lupus erythematosus patients. Lupus 2006;15:268-75.

5 Ruiz-Irastorza G, Ramos-Casals M, Brito-Zeron P, et al. Clinical efficacy and side effects of antimalarials in systemic lupus erythematosus: a systematic review. Ann Rheum Dis 2010;69:20-8.

6 Ruiz-Irastorza G, Egurbide MV, Pijoan Jl, et al. Effect of antimalarials on thrombosis and survival in patients with systemic lupus erythematosus. Lupus 2006;15:577-83.

7 Xibillé-Friedmann D, Pérez-Rodríguez M, Carrillo-Vázquez S, et al. Clinical practice guidelines for the treatment of systemic lupus erythematosus by the Mexican College of rheumatology. Reumatol Clin 2019;15:3-20.

8 Pons-Estel BA, Bonfa E, Soriano ER, et al. First Latin American clinical practice guidelines for the treatment of systemic lupus erythematosus: Latin American Group for the Study of Lupus (GLADEL, Grupo Latino Americano de Estudio del Lupus)Pan-American League of Associations of Rheumatology (PANLAR). Ann Rheum Dis 2018;77:1549-57

9 Gordon C, Amissah-Arthur M-B, Gayed M, et al. The british Society for rheumatology guideline for the management of systemic lupus erythematosus in adults. Rheumatology 2018;57:e1-45. 